\title{
THE ACHIEVEMENT-ORIENTED LEADERSHIP MODEL IN THE DEVELOPMENT OF THE MALAYSIAN NATION-STATE
}

\author{
Khairul Azman Mohamad Suhaimy, ${ }^{1 *}$ Nurul Aimi Razali, ${ }^{2^{* *}}$ Lutfan Jaes, ${ }^{3}$ \\ Muhamad Helmy Sabtu, ${ }^{4}$ Muhammad Fuad Othman, ${ }^{5}$ Mohamad Ainuddin \\ Iskandar Lee Abdullah, ${ }^{6}$ \& Mohd. Shukri Hanapi ${ }^{7}$ \\ ${ }^{*}$ First author*, ${ }^{* *}$ corresponding author \\ 1,2,3,4Centre for General Studies and Co-curricular, Universiti Tun Hussein Onn \\ Malaysia \\ 5,6College of Law, Government and International Studies, Universiti Utara \\ Malaysia
}

${ }^{7}$ Centre for Islamic Development Management Studies, Universiti Sains Malaysia (khairula@uthm.edu.my, aimirazali@yahoo.com, lutfan@uthm.edu.my, mhelmy_2211@yahoo.com,mfuad@uum.edu.my, ainuddin@uum.edu.my, hshukri@usm.my) DOI: https://doi.org/10.22452/jati.vol26no1.1

\begin{abstract}
In the administration and development of the Malaysian nation-state, each prime minister has contributed and exhibited his distinct leadership style. Abdul Razak Hussein and Mahathir Mohamad's contributions and leadership, especially in the nation-state's development and modernisation, are well-recognised by Malaysians. They referred to Razak as the Development Father while Mahathir is known as the Father of Modernisation. Their leaderships' effectiveness is also evident in their outstanding achievements based on the policies and actions during their tenure as the nation's leaders. Therefore, this study aims to discuss the achievement-oriented aspects of Razak-Mahathir leadership in Malaysia's nation-state development. A qualitative historical descriptive design was used as the research methodology where the primary source of this study was the texts of the two prime ministers' speeches. These sources are qualitatively analysed to explore the qualities of leadership they practised to develop and modernise the country. The results showed that leadership qualities such as stimulating people's intellectual capacity, motivating people, good planning, demonstrating influence, emphasising togetherness, emphasising good values, exhibiting firmness, demonstrating self-confidence, being considerate, envisioning the future and acknowledging people's contribution were practised by Razak and Mahathir in conducting their duties as prime ministers. It showed that a country can achieve
\end{abstract}


remarkable development and modernisation when it is led by leaders who incorporate the aforementioned leadership qualities. This study's social implications are as follows: first, underlining the importance of achievementoriented leadership that can inspire the people and the government to foster a steady national development and secondly, implying the essential roles of leaders in defining and shaping a suitable nation-state concept that should be adopted in a nation-state. This study innovatively introduces a leadership model framework based on Razak-Mahathir's achievements during their administration. It gives an overview of their successful leadership styles in governing the country, which can be applied or practised by leaders or related parties with similar roles, aspirations and goals.

Keywords: Abdul Razak Hussein, Mahathir Mohamad, achievement-oriented, leadership model framework, nation-state

\section{Introduction and Background}

Abdul Razak Hussein and Mahathir Mohamad are well known for their unique leadership and contributions to ensure Malaysia's development and modernisation. Razak is known for his calm and patient character but proactive in managing and governing the country's development. Policies and actions taken had become fundamental to the successful mobilisation and development of the country's core agricultural sector. In contrast, Mahathir is known for his outspoken and robust character, yet through his administration and drive, he pushed Malaysia's nation-state towards modernisation. Although many doubt his vision, his policies and actions are policies and concepts that have emerged as the basis of Malaysia's modernisation (Omar \& Pandian, 2006). In addition to policies that provided employment opportunities and stimulating industrialisation in Malaysia, Mahathir also launched policies to develop human capital (Omar \& Pandian, 2006; Welsh, 2005). He is well-known for his insistence that a nation's civilisation may not be perfect in terms of the development of its physical infrastructure and progress, but the development and progress of the people as the human capital of the nation is just as important as these two qualities are complementary (Jaes, 2017; Mohamad \& Ibrahim, 1994; Suhaimy, 2009). Bearing in mind that the country's economic, political, and social sectors must be curated as best as possible, Mahathir is one of the leading people to champion such a move.

Razak was a proactive country leader in introducing and implementing policies and actions that were focused on driving and strengthening the development of Malaysia. Similarly, Mahathir was regarded as a thoughtful and holistic leader in transforming Malaysia's nation-state through his policies, 
projects, development ideas, and the modernisation of an advanced nation-state. Under both Razak and Mahathir's leaderships, Malaysia has successfully progressed way ahead of most developing countries. These achievements reflect the accomplishment of their leadership to lead the governance of Malaysia. Therefore, this study aims to identify Razak and Mahathir's achievement-oriented leadership qualities in their governing of the Malaysian nation-state, especially in terms of development and modernisation.

\section{Literature Review}

\section{Father of Development of Malaysia-Abdul Razak Hussein}

Abdul Razak Hussein was Malaysia's second prime minister. Although he served as the prime minister for a short period, for five years from September 22, 1970, to January 14, 1976, his leadership and contribution to the country's development and progress began before becoming the prime minister. Razak became involved with the state administration in 1954 as a minister in various ministries for 15 years. During which time, he also held his portfolio as deputy prime minister for 13 years. He also served as the Director of the National Operations Council or Majlis Gerakan Negara (MAGERAN) from May 1969 for 21 months. He was subsequently appointed as prime minister in September 1970 (Nik Mahmud, Salleh, \& Harun, 2011). His contribution to Malaysia's nation-state development was significant, and it qualified him to be recognised as the Father of Development or Bapa Pembangunan in Malay (National Archives of Malaysia, 2019). The launching of policies and the establishment of institutions led by him showed that they benefitted the country and the people.

Among his most outstanding initiatives before becoming prime minister were the Razak Report 1956, which aimed to unite multiracial Malaysians; National Education Policy 1957 was aimed to support the Malay language as the national language to create unity (Rudner, 1977). The Red Book 1960 was aimed at empowering rural development where it was used to record each district's plans, including its progress and failure. Also, the establishment of a government agency, the Federal Land Development Authority or Lembaga Kemajuan Tanah Persekutuan (FELDA) strengthened land use and the agricultural sector; the establishment of Majlis Amanah Rakyat (MARA) and the National Corporation or Perbadanan Nasional Berhad (PERNAS) encouraged the participation of the Malays and Bumiputras in the business sector (National Archives of Malaysia, 2019; Nik Mahmud, Salleh, \& Harun, 2011). Another notable achievement was his role as a peacemaker during the Malaysia Formation process in 1963, where he was appointed Minister of Defence, that received opposition from certain parties. Later, as the Director of MAGERAN, he restored peace, promoted harmony, and 
restored the trust in the government after the May 13, 1969 tragedy. The Rukun Negara was then introduced as the key means of sustaining peace among the people.

His leadership continued to be prominent, and his contribution to the nation-state's development was even more significant when he became the prime minister. He launched the New Economic Policy in 1970 aimed at eradicating poverty regardless of race and restructuring the nation by abolishing racial identity through economic activity. In 1971, he launched the National Cultural Policy, which emphasised local elements and the need for the appropriate cultures of the other races to be accepted and celebrated. In the same year, he also led the Southeast Asia Exemption Policy to make the region free, safe, and neutral. Subsequently, in the aspect of national politics, he successfully introduced the politics of accommodation in 1974 through Barisan Nasional, which saw cooperation between the ruling party, the United Malays National Organisation or Pertubuhan Kebangsaan Melayu Bersatu (UMNO) and other component parties. This effort allowed the opposition parties to cooperate to establish a more mature political practice than the confrontational politics that previously coloured the country's politics.

In the same year, he pioneered bilateral relations with the People's Republic of China, known for its political and socialist ideologies, for the sake of the country's peace and stability. Indeed, the initiative had positive implications for Malaysia and Southeast Asia, which were once the target of the Communist movement. The policies, initiatives, and actions taken by him proved that he was an innovative and fundamental leader. His leadership had undoubtedly given rise to several new vital sectors to drive the nation-state's development. He had succeeded in laying a strong foundation for the development of the Malaysian nation-state, as evidenced by the functioning of the agencies he had initiated and the fact that the policies he pioneered can still be enjoyed by Malaysians today.

\section{Father of Modernisation of Malaysia - Mahathir Mohamad}

Mahathir Mohamad was the fourth and the seventh Malaysian prime minister. He was the only prime minister who had served the longest and served twice. He led the country's administration as the fourth prime minister from June 28, 1981, to October 31, 2003, for 22 years and, as the seventh, from May 10, 2018, to February 24, 2020, before acting as the interim prime minister from the date until March 1, 2020 (Abdullah, 2019; Ong, 2005). His leadership and contributions were undeniable, even though some considered him an autocratic dictator (Cheah \& Ahmad, 2017; Omar \& Pandian, 2006; Ong, 2005; Suppiah, Ahmad \& Gunasekaran, 2018). Whether old or new, his leadership is essential and beneficial 
to the country's administration and development. During his leadership as the fourth prime minister, Malaysia experienced sustainable development and revitalised modernisation until Malaysians accredited him as the Father of Modernisation (Cheah \& Ahmad, 2017; Omar \& Pandian, 2006; Suppiah, Ahmad \& Gunasekaran, 2018).

Like Razak, Mahathir was also active in advancing the people and the country before becoming prime minister. He became aware of the issues that inhibit the progress of the Malays in Malaya when he was still young. He had a fighting spirit and high aspirations to help the Malays become more advanced in the education and economy fields without neglecting other races' opportunities and rights (Omar \& Pandian, 2006; Ong, 2005). In addition to his significant contribution to the nation-state's development during his youth, the initiatives he took, and his contributions were even more significant when he took office at the federal level as his initiatives were policy-based, applicable for all Malaysians. Among his significant contributions was he reformed the National Education Policy to eradicate poverty and provide justice to all people through education. This act also amended the Universities and Colleges Act 1974, which aimed to put the university administration under the Ministry of Education control when he became Minister of Education in 1974 (Ibrahim, 2007; Sundaram \& Cheek, 1988).

Mahathir's leadership and contribution to the development and modernisation of the Malaysian nation-state became comprehensive when he became prime minister. Various national policies, directions, and mega projects were launched with the intention to develop the nation and its people. Like Razak, the initiatives taken by Mahathir were also fundamental. His initiatives consisted of programmes that changed the thinking patterns, living culture, work ethics, education system, and economic empowerment of the Malaysian people (Cheah \& Ahmad, 2017; Omar \& Pandian, 2006; Ong, 2005; Suppiah \& Gunasekaran, 2018). These programmes were beneficial to Malaysians based on the significant changes seen amongst Malaysians in the relevant and essential areas as they became increasingly prepared for the process of globalisation. Among his contributions were strengthening the country's administration through ensuring the uniformity of systems and ways of working, which included the use of a timecard system, name tag identification, file storage systems, correspondence and postal arrangements, guidance, and coordination in all office matters (Hussain, 1997; Rohman \& Sabri, 2017). This process was further strengthened by injecting good values and good work ethics by launching programmes and policies such as the Clean, Efficient and Trusted Campaign; Leadership by Example; Implementation of Islamic Values; and Look East Policy (Furuoka, 2007; Rohman \& Sabri, 2017). While the main aim of these programmes and policies was to 
strengthen work ethics at the public administration level involving national leaders and civil servants, these programmes' benefits indirectly impact Malaysians' core values. This transformation was achieved as they emulated examples represented by leaders and civil servants; as a government ambassador to other Malaysians (Rohman \& Sabri, 2017).

The strengthening of the economic sector can be seen through the launch of the Malaysian Incorporated Policy to build a partnership between the government and the private sector in creating an industry-concept country where the profits will be shared (Wiliamson, 2002). This policy had undoubtedly taken Malaysia to a better level as its economy improved and strengthened over the years since its launch. For nearly a decade, the economy had grown at an annual rate of 8 (Mohamad, 1996). Mahathir's success in managing the country's economy was evident when he prevented the country from being affected by the 1997-1998 Asian Financial Crisis by linking the Malaysian Ringgit to the American Dollar (Haggard, 2000). This act was significant and demonstrated his leadership's credibility and legitimacy. It contributed to the country's economic sustainability by preventing Malaysia from experiencing an economic downturn and deepening debt.

In his quest to drive holistic modernisation for the nation-state, Mahathir launched Vision 2020 that served as the cornerstone guide to achieving the goal of an advanced country and remain systematic in its economy, infrastructure, science, and technology (Khattab, 2004; Nathan, 1995). Megaprojects such as the construction of the administrative centre of Putrajaya, Kuala Lumpur City Centre (KLCC), Kuala Lumpur International Airport (KLIA) dan Multimedia Super Corridor (MSC) Malaysia were undertaken to achieve this vision (Bunnell, Barter \& Morshidi, 2002; Beng, 2006; Embong, Hassan, \& Ibrahim, 2016; Jackson \& Mosco, 1999; Taylor, 2003). As a developing country, these visions and projects were considered futuristic in that they were not the norms of developing countries. While this vision was not achieved to a greater extent due to some changes in the country's political and administrative landscape, the benefits of the projects had been enjoyed by Malaysians (Raj, Wahab, Osman, Zawawi \& Fazal, 2018).

It is undeniable that these projects and visions had succeeded in modernising Malaysia, which is now sustainable due to the past prime minister's leadership. These proud achievements have elevated Mahathir's credibility as a prime minister and placed him in his own league. His leadership's legitimacy continued when the people gave him the mandate to become the seventh prime minister after the Alliance of Hope or Pakatan Harapan (PH) won the 14th general election (Abdullah, 2019). Mahathir's leadership during both administration periods demonstrated different but positive dynamics because of the differences 
in the past and present governmental conditions. However, this study focuses only on Mahathir's leadership as the fourth prime minister when he was referred to as the Modernisation Father.

\section{Development of Nation-State}

The nation-state concept has emerged since the $15^{\text {th }}$ century following the rise of the state's modern system, better known as the "Westphalian system". The result of the Treaty of Westphalia in 1648 after the Thirty Years' War between the Catholics and Protestants in the Holy Roman Empire, German, sparked the religious divide throughout Europe (Osborne, 2018). The Westphalian system did not create a nation-state, but a nation-state established the system's criteria as part of its component. The criteria of the system include that every state has authority over its space and national matters, to the barring of all peripheral controls, on the norm of non-intervention in another state's national matters, and that every state, whether small or large, is the same in transnational law (Jonas \& Wilson, 2018). A nation-state is defined as a state that conjoins the political entity to the cultural entity. It aims to derive its political legitimacy from ruling and potentially from the status as a sovereign state (Embong, 2001). Technically, the nation-state concept is a blend between nation and state, a formation based on the unification of nations and reinforced by a particular territory's boundaries as an identity. According to Ahmad Fawzi Basri, Abdul Halim Ahmad, and Abdul Ahmad Aziz (1987), as well as Mohammad Redzuan Othman (2006), nation-states are born in modern times where their people are of various ethnicities, religions, and cultures.

A nation-state has a combination of three main components, namely the individual, the state, and the nation (Embong, 2001). Individuals are fundamental to forming a state and a nation because every interaction between them will influence the other people and form a group with common characteristics and interests that will eventually create a state with its motive for government and the creation of a nation. A state is a group of human beings living in a country. A large group whose members share the same beliefs and are bound by a specific identity that forms a group of people with similarities through historical, cultural, and genealogical connections. A nation is a political unit with power, sovereignty, responsibility and is not tied to any party in carrying out its agenda. Abdul Rahman Embong (2001) also emphasised that a country should have sovereignty, people, territories, and a valid government. In addition to combining the three components, a nation-state must have the following characteristics: multiracial society, living in solidarity, sharing political ideology, and having confidence and belief in the system of government and constitution and the law. 
While the catalyst factors for establishing a successful nation-state are democracy, nationalism, patriotism, and integration, the nation-state in the context of Malaysia is a state shaped by historical, political, economic, and social factors; and finally consolidated with the expression "Malaysian nation-state" (Baharuddin, 1990; Embong, 2001). The "Malaysian nation-state" is the people living in Malaysia, sharing their cultures, economies, territories, and future destiny with one state's appearance. In this study, Malaysia's development of a nation-state refers to Malaysia's development as a nation comprising all its multiracial people.

This study focuses on Razak and Mahathir's roles in discussing the development of the Malaysian nation-state due to their apparent achievements. Under their administration, the Malaysian nation-state has prospered in its development and modernisation. Their roles are aligned, as claimed by Abdul Rahman Embong (2001) who stressed the importance of a valid government's role in developing a nation-state. Razak and Mahathir had played their important roles as the country's leaders in developing and modernising Malaysia as a nation-state.

Under the Razak administration, Malaysia introduced and implemented the New Economic Policy, an affirmative policy. First, it aimed to reduce and eradicate poverty by increasing the income and employment opportunities for all Malaysians regardless of race. Secondly, it aimed to accelerate the Malaysian economy's restructuring to correct economic imbalances, reduce and subsequently eliminate racial identification according to their economic functions. This policy achieved its goal because it reduced the poverty rate from $49.3 \%$ in 1970, the year the policy was implemented, to $17.1 \%$ in 1990, the final year of policy implementation (Jomo \& Sundaram, 2004). Meanwhile, several advanced strategies were then implemented to achieve the objectives of these two policies.

Next, under Mahathir's administration, Malaysia's apparent successes included encouraging economic growth at a rate of 7 per cent every year, starting in the 1990s (Hussin, 1999; Mohamad, 2012). The National Development Policy started in 1991, aimed first to strengthen the country's economic, social and political stability through urban and rural developments. Second, to make Malaysia a developed country and strengthen its social justice, ethical values, morals, quality of life, and to practise fair administration and economic excellence principles, which he implemented to the continuation of the New Economic Policy. The policy proved successful in increasing its economic growth, which increased from year to year, despite a world economic crisis that disrupted most countries' economic growth, which did not spare Malaysia.

Based on their achievements, the importance of their leadership in the Malaysian government administration is undeniable. They might have a set of similar achievement-oriented leadership qualities in governing, allowing them to 
lead the development of the Malaysian nation-state. Thus, this study aims to determine Razak and Mahathir's achievement-oriented leadership qualities, especially in Malaysia's nation-state development and modernisation.

\section{Methodology}

The design of the research methodology is qualitative historical descriptive. According to Morgan and Smircich (1980) and Danto (2008), this design enables a given past situation, condition, or event to be described and interpreted. Besides, this design can also show the patterns and actions that have been used in a given situation (Mcdowell, 2013). This design is in line with this study's nature, which studies Razak and Mahathir's leadership qualities in carrying out the policies and actions of developing and modernising the nation-state based on the existing resources. The primary source is the text of the two prime ministers' speeches.

These resources are qualitatively analysed through thematic analysis to explore the leadership qualities they practiced in implementing national administration policies to develop and modernise the country. According to Boyatzis (1998), thematic analysis is "a process for encoding qualitative information that can be thought of as a bridge between qualitative and quantitative research". The analysed speech texts were in conjunction with the speeches to mark the New Year and National Day celebrations. The speech texts were obtained from the National Archives of Malaysia's website. Both types of speech texts were chosen because these speech texts were intended for all Malaysians. It enables the prime ministers' leadership qualities to lead the development of the nation-state of Malaysia to be analysed thematically. The qualities of leadership were then conceptualised into a leadership model framework and discussed.

Table 1: The Speech Texts of Abdul Razak Hussein and Mahathir Mohamad

\begin{tabular}{|c|c|c|c|c|c|}
\hline \multicolumn{3}{|c|}{ Abdul Razak Hussein } & \multicolumn{3}{|c|}{ Mahathir Mohamad } \\
\hline Year & Text & $\begin{array}{l}\text { Text } \\
\text { Code }\end{array}$ & Year & Text & $\begin{array}{l}\text { Text } \\
\text { Code }\end{array}$ \\
\hline 1971 & $\begin{array}{l}\text { The message of the } \\
\text { prime minister of the } \\
\text { National Day }\end{array}$ & S1 & 1982 & $\begin{array}{l}\text { The message of the } \\
\text { prime minister of the } \\
\text { National Day }\end{array}$ & S10 \\
\hline \multirow[t]{2}{*}{1972} & $\begin{array}{l}\text { The message of the } \\
\text { prime minister of the } \\
\text { New Year }\end{array}$ & S2 & \multirow[t]{2}{*}{1983} & $\begin{array}{l}\text { The message of the } \\
\text { prime minister of the } \\
\text { New Year }\end{array}$ & S11 \\
\hline & $\begin{array}{l}\text { The message of the } \\
\text { prime minister of the } \\
\text { National Day }\end{array}$ & S3 & & $\begin{array}{l}\text { The message of the } \\
\text { prime minister of the } \\
\text { National Day }\end{array}$ & S12 \\
\hline
\end{tabular}


Khairul Azman Mohamad Suhaimy, Nurul Aimi Razali, Lutfan Jaes, Muhamad Helmy Sabtu, Muhammad Fuad Othman, Mohamad Ainuddin Iskandar Lee Abdullah, E Mohd Shukri Hanapi

\begin{tabular}{|c|c|c|c|c|c|}
\hline \multirow[t]{2}{*}{1973} & $\begin{array}{c}\text { The message of the } \\
\text { prime minister of the } \\
\text { New Year }\end{array}$ & $\mathrm{S} 4$ & \multirow[t]{2}{*}{1984} & $\begin{array}{c}\text { The message of the } \\
\text { prime minister of the } \\
\text { New Year }\end{array}$ & S13 \\
\hline & $\begin{array}{c}\text { The message of the } \\
\text { prime minister of the } \\
\text { National Day }\end{array}$ & S5 & & $\begin{array}{c}\text { The message of the } \\
\text { prime minister of the } \\
\text { National Day }\end{array}$ & S14 \\
\hline \multirow[t]{2}{*}{1974} & $\begin{array}{c}\text { The message of the } \\
\text { prime minister of the } \\
\text { New Year }\end{array}$ & S6 & \multirow[t]{2}{*}{1985} & $\begin{array}{c}\text { The message of the } \\
\text { prime minister of the } \\
\text { New Year }\end{array}$ & S15 \\
\hline & $\begin{array}{c}\text { The message of the } \\
\text { prime minister of the } \\
\text { National Day }\end{array}$ & S7 & & $\begin{array}{l}\text { The message of the } \\
\text { prime minister of the } \\
\text { National Day }\end{array}$ & S16 \\
\hline \multirow[t]{2}{*}{1975} & $\begin{array}{c}\text { The message of the } \\
\text { prime minister of the } \\
\text { New Year }\end{array}$ & S8 & \multirow[t]{2}{*}{1986} & \multirow[t]{2}{*}{$\begin{array}{c}\text { The message of the } \\
\text { prime minister of the } \\
\text { New Year }\end{array}$} & \multirow[t]{2}{*}{$\mathrm{S} 17$} \\
\hline & $\begin{array}{c}\text { The message of the } \\
\text { prime minister of the } \\
\text { National Day }\end{array}$ & S9 & & & \\
\hline
\end{tabular}

Table 1 shows 17 speech texts, 9 of which are delivered by Razak, and eight speech texts are delivered by Mahathir. Razak's speeches include the New Year's speech and the National Day's speech from 1971 to 1975, while Mahathir's texts include the speeches from 1982 to 1986. Since Razak took power in September 1970, his first year in office has surpassed the New Year's and National Day celebrations. As a result, speech texts from his second to sixth years in office were used in this study to cover his first five years in office. Meanwhile, for Mahathir, as he was in charge of the country's administration from June 1981, his speech text for this study began with his first National Day speech. This indicated that the New Year's celebration date for that year had passed. In exchange, his New Year's speech from 1986 was included to cover his first five years in office. The first five years of administration were chosen as the time frame for this study. This period was a crucial period in which a leader and his governing government introduced and strengthened an action plan to govern a country's development (Suhaimy, 2009). Although the same amount of text for each leader was attempted for this study, three related speech texts could not be obtained. The speech text was the text of Razak's speech on the New Year's celebration in 1971. Meanwhile, the speech text delivered by Mahathir, which could not be obtained, was the speech text on the New Year's celebration in 1982 and the text of the National Day speech in 1986. 


\section{Analysis}

This study shows that Razak and Mahathir share the same qualities of achievement-oriented leadership in leading the development of the Malaysian nation-state. These qualities are stimulating people's intellectual capacity, motivating people, careful planning, demonstrating influence, emphasising togetherness, emphasising good values, exhibiting firmness, demonstrating selfconfidence, being considerate, envisioning the future and acknowledging people's contribution.

Table 2: Leadership Qualities of Abdul Razak Hussein

\begin{tabular}{|c|c|c|c|c|c|c|c|c|c|c|c|}
\hline $\begin{array}{c}\text { Tex } \\
\text { t } \\
\text { Co } \\
\text { de }\end{array}$ & $\begin{array}{c}\text { Well- } \\
\text { Planni } \\
\text { ng }\end{array}$ & $\begin{array}{c}\text { Exhibit } \\
\text { ing } \\
\text { Firmne } \\
\text { ss }\end{array}$ & $\begin{array}{c}\text { Demonstra } \\
\text { ting Self- } \\
\text { confidence }\end{array}$ & $\begin{array}{c}\text { Envision } \\
\text { ing } \\
\text { Future }\end{array}$ & $\begin{array}{c}\text { Demonstra } \\
\text { ting } \\
\text { Influence }\end{array}$ & $\begin{array}{l}\text { Emphasis } \\
\text { ing } \\
\text { Together } \\
\text { ness }\end{array}$ & $\begin{array}{c}\text { Stimulat } \\
\text { ing } \\
\text { People's } \\
\text { Intellect } \\
\text { ual } \\
\text { Capacity }\end{array}$ & $\begin{array}{l}\text { Motivat } \\
\text { ing } \\
\text { people }\end{array}$ & $\begin{array}{c}\text { Being } \\
\text { Conside } \\
\text { rate }\end{array}$ & $\begin{array}{c}\text { Acknowled } \\
\text { ging } \\
\text { People's } \\
\text { Contributio } \\
\text { n }\end{array}$ & $\begin{array}{c}\text { Emphasis } \\
\text { ing Good } \\
\text { Values }\end{array}$ \\
\hline S1 & 6 & 4 & 4 & 3 & 6 & 11 & 9 & 15 & 5 & 1 & 1 \\
\hline S2 & 6 & 0 & 4 & 2 & 7 & 2 & 6 & 3 & 1 & 1 & 1 \\
\hline S3 & 3 & 3 & 6 & 0 & 2 & 1 & 14 & 8 & 4 & 3 & 5 \\
\hline S4 & 7 & 0 & 1 & 3 & 6 & 2 & 6 & 4 & 3 & 1 & 2 \\
\hline S5 & 6 & 1 & 6 & 2 & 3 & 4 & 8 & 5 & 4 & 3 & 5 \\
\hline S6 & 8 & 7 & 2 & 2 & 2 & 6 & 9 & 10 & 0 & 3 & 2 \\
\hline S7 & 7 & 4 & 8 & 3 & 6 & 3 & 8 & 3 & 2 & 3 & 5 \\
\hline S8 & 12 & 4 & 4 & 2 & 9 & 5 & 11 & 4 & 3 & 1 & 4 \\
\hline S9 & 5 & 0 & 6 & 0 & 10 & 5 & 12 & 4 & 1 & 2 & 0 \\
\hline $\begin{array}{c}\text { Tot } \\
\text { al }\end{array}$ & 60 & 23 & 40 & 17 & 51 & 39 & 83 & 56 & 23 & 18 & 25 \\
\hline
\end{tabular}

According to Table 2, stimulating people's intellectual capacity is the most prominent quality of Razak's leadership in his speeches, with a frequency of 83. It is followed by the quality of being able to plan well and his efforts to lead and motivate people, with a frequency of 60 and 56, respectively. Other leadership qualities that Razak moderately demonstrates are self-confidence and togetherness, with a frequency of 40 and 39, respectively. Finally, the leadership qualities that he highlights in low frequency are envisioning the future and acknowledging people's contribution.

Table 3: Leadership Qualities of Mahathir Mohammad

\begin{tabular}{|c|c|c|c|c|c|c|c|c|c|c|c|}
\hline $\begin{array}{c}\text { Tex } \\
t \\
\text { Co } \\
\text { de }\end{array}$ & $\begin{array}{c}\text { Well- } \\
\text { Planni } \\
\text { ng }\end{array}$ & $\begin{array}{c}\text { Exhibit } \\
\text { ing } \\
\text { Firmne } \\
\text { ss }\end{array}$ & $\begin{array}{l}\text { Demonstra } \\
\text { ting Self- } \\
\text { confidence }\end{array}$ & $\begin{array}{l}\text { Envision } \\
\text { ing } \\
\text { Future }\end{array}$ & $\begin{array}{c}\text { Demonstra } \\
\text { ting } \\
\text { Influence }\end{array}$ & $\begin{array}{l}\text { Emphasis } \\
\text { ing } \\
\text { Together } \\
\text { ness }\end{array}$ & $\begin{array}{c}\text { Stimulat } \\
\text { ing } \\
\text { People's } \\
\text { Intellect } \\
\text { ual } \\
\text { Capacity }\end{array}$ & $\begin{array}{c}\text { Motivat } \\
\text { ing } \\
\text { People }\end{array}$ & $\begin{array}{c}\text { Being } \\
\text { Conside } \\
\text { rate }\end{array}$ & $\begin{array}{c}\text { Acknowled } \\
\text { ging } \\
\text { People's } \\
\text { Contributio } \\
\text { n }\end{array}$ & $\begin{array}{c}\text { Emphasis } \\
\text { ing Good } \\
\text { Values }\end{array}$ \\
\hline S10 & 5 & 5 & 2 & 0 & 3 & 5 & 18 & 7 & 0 & 1 & 3 \\
\hline S11 & 5 & 0 & 0 & 1 & 6 & 8 & 12 & 7 & 4 & 0 & 6 \\
\hline $\mathrm{S} 12$ & 1 & 2 & 0 & 2 & 0 & 8 & 7 & 4 & 0 & 0 & 1 \\
\hline $\mathrm{S} 13$ & 3 & 0 & 0 & 2 & 3 & 3 & 7 & 5 & 0 & 2 & 5 \\
\hline S14 & 2 & 0 & 0 & 2 & 7 & 0 & 16 & 5 & 0 & 0 & 7 \\
\hline S15 & 4 & 4 & 0 & 2 & 2 & 4 & 11 & 4 & 0 & 0 & 8 \\
\hline S16 & 2 & 3 & 0 & 1 & 2 & 0 & 13 & 4 & 0 & 1 & 3 \\
\hline S17 & 3 & 6 & 1 & 0 & 4 & 1 & 16 & 7 & 1 & 0 & 5 \\
\hline $\begin{array}{c}\text { Tot } \\
\text { al }\end{array}$ & 25 & 20 & 3 & 10 & 27 & 29 & 100 & 43 & 5 & 4 & 38 \\
\hline
\end{tabular}


According to Table 3, stimulating people's intellectual capacity is the most prominent quality of Mahathir's leadership in his speeches, with a frequency of 100. It is followed by the ability to motivate people and emphasise good values, with a frequency of 43 and 38, respectively. Mahathir accentuates other leadership qualities that focus on the sense of togetherness and demonstrating influence, with a frequency of 29 and 27, respectively. He underlines the need to be considerate, acknowledge people's contribution, and demonstrate self-confidence in his speeches, albeit with a low frequency.

Razak and Mahathir's similarity is that stimulating people's intellectual capacity is identified as the quality with the highest frequency, while the leadership quality of acknowledging people's contribution scores the lowest frequency. Meanwhile, the significant difference between the leadership qualities emphasised by both the leaders is that Razak frequently emphasises the quality of demonstrating self-confidence, while Mahathir often emphasises the practice of good values in leadership. Practically, Razak's leadership is oriented towards stimulating people's intellectual capacity, careful planning, and motivating people. In contrast, Mahathir focuses on the qualities of stimulating people's intellectual capacity, motivating people, and emphasising the practice of good values in leading.

\section{Findings and Discussions}

This study analysed all 17 speech texts delivered by Razak and Mahathir in conjunction with the New Year and National Day. Based on an in-depth analysis of each speech text, 11 themes of leadership qualities with a total frequency of 739 the core of Razak and Mahathir's leadership qualities during their administrations. The findings revealed that both leaders highlighted aspects of leadership, including stimulating people's intellectual capacity, motivating people, careful planning, demonstrating influence, emphasising togetherness, emphasising good values, exhibiting firmness, demonstrating self-confidence, being considerate, envisioning the future and acknowledging people's contribution as illustrated in Figure 1. Figure 1 is the constructed Razak-Mahathir achievement-oriented leadership model framework based on the themes extracted from the analysis. 


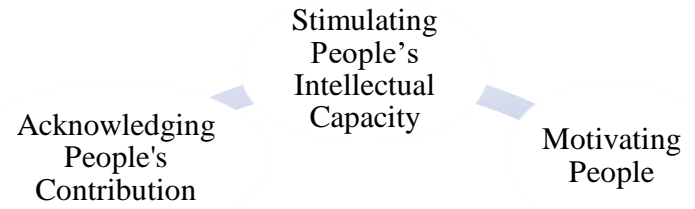

People's
Contribution

Envisioning

Future

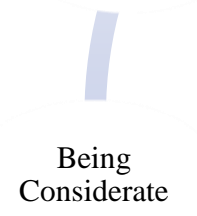

Demonstrating

Self-confident

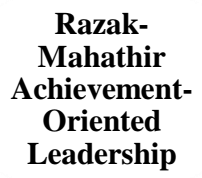

Emphasising

Togetherness
Careful

planning

Demonstrating Influence

\section{Exhibiting Emphasising}

firmness $\perp$ Good Values

\section{Figure 1 - Razak-Mahathir Achievement-Oriented Leadership Model Framework}

Razak dominated his leadership with qualities of stimulating people's intellectual capacity, careful planning and motivating people to lead the country. It is almost identical to Mahathir's leadership qualities as apparent in his administration, which were to stimulate people's intellectual capacity and motivate people. However, it was different from the third quality of Mahathir's leadership: cultivating good values. Razak and Mahathir's leadership emphasised the stimulation of people's intellectual capacity as it could inform the people of the reasons and purposes of a matter that needs to be accomplished. Subsequently, it mobilises them to take appropriate action to achieve the goal (Abdullah, 2019; Cheah, Yusof \& Ahmad, 2017; Suppiah, Ahmad, \& Gunasekaran, 2018). During the administration of these two prime ministers, it is critical to consider the background of Malaysians in the discussion of their leadership qualities.

During Razak's administration, Malaysia had just reached its fourteenth year of independence; relatively, the people were still new to the idea of development and needed a leader who can lead and move them towards development. In light of this, the leadership qualities of stimulating people's 
intellectual capacity and motivating people as underlined by Razak were very appropriate to navigate this situation. The other quality that dominated Razak's leadership, which was careful planning, was crucial for him during the his administration and leadership from the late 1971 until early 1976. Following the leadership qualities of stimulating people's intellectual capacity and motivating people, the quality of careful planning was necessary because the people needed a clear guidance on how a goal is to be accomplished, such as the necessary actions that needed to be executed to realise an identified goal (Lovelace, Neely, Allen, \& Hunter, 2019; McCleskey, 2014). Therefore, Razak's role in defining people's structured actions in achieving national development's desires and goals are essential. In discussing Razak's leadership in terms of Malaysia's nation-state development, he was undoubtedly forward-thinking about its future and people. His efforts to develop the nation-state of Malaysians lie well within the New Economic Policy, enabling every multi-ethnic Malaysian to work together and fairly compete once equality is established among them (Arifin \& Othman, 2018). His leadership in mobilising the efforts of developing a nation-state of Malaysia is undeniable in its importance as it is the basis for the current Malaysian nationstate. However, the narrative is still vague and requires extensive academic research and discussion.

Meanwhile, during the first five years of Mahathir's administration from 1981 to 1986, Malaysians enjoyed independence for 24 years. The people have been well informed about the development process of the three former Prime Ministers, Abdul Rahman Putra, Razak, and Hussein Onn. However, the people were still new to the idea of developing and modernising a nation-state of Malaysia brought by Mahathir in leading the country towards world-class progress. Therefore, given the circumstances of the people who were not yet fully aware of the idea of modernisation, Mahathir's approach was crucial. The qualities of stimulating people's intellectual capacity and motivating people that Mahathir highlighted in governing and leading the country's momentum towards modernisation were indeed needed. The people needed the reason and rationale to justify the idea of modernisation (McCleskey, 2014; Sendjaya, Pekerti, Härtel, Hirst, \& Butarbutar 2016; van Houwelingen, van Dijke \& De Cremer, 2015), and this can be advanced by an intellectually stimulating leader. The leader has the ability to facilitate and create awareness in his followers regarding problems, their own thoughts, and recognition of their own views and ideals (Alqahtani, 2020; Liu, Dust, Xu, \& Ji, 2021). Mahathir succeeded in identifying the people's needs as he was able to explain to the people about any actions taken by the government. He was also relentless in providing examples and comparisons that were taking place worldwide so Malaysians can comprehend the reason and rationale for his 
decisions and actions. For example, Mahathir explained why his government is democratic but following the convention of the local rules (Omar \& Pandian, 2006). He cited that the practice of democracy in Western countries would indefinitely lead to moral decline, and this is followed by explaining why the Western practice of democracy is not suitable to be practised in Malaysia. By doing so, Mahathir indirectly inspired the people's motivation to work together towards modernisation. Motivating people was also crucial as it moved the people towards achieving the nation-state's common desired goals once they understood the reasons and rationale behind his ideas.

Another quality of leadership that dominated Mahathir's leadership is the cultivation of good values in leadership. Mahathir is well known for his perseverance in cultivating the practice of good values among Malaysians (Suhaimy, 2009; Jaes, 2017). This study's speech texts also proved that Mahathir was active in instilling good values among Malaysians, especially in the early days of his administration's. He desired that Malaysians adopt a positive life-value system so that their lifestyle and work ethic can be enhanced and empowered to facilitate the country's modernisation agenda's mobilisation and achievement.

In line with Razak's efforts in spearheading the Malaysian nation-state's development, Mahathir was no less remarkable in shaping and steering the Malaysian nation-state. He openly fought for the Malaysian state in Vision 2020, launched in 1991. Although many said the Malaysian state's definition is unclear, Mahathir was evident in his struggle to form his nation-state. He took care of the rights and privileges of the Malays and Bumiputra as a native of Malaysia without ignoring the rights of the Chinese, Indian, and other races (Abdullah, 2019; Cheah, Yusof, \& Ahmad, 2017; Suppiah, Ahmad, \& Gunasekaran, 2018). Although cynical names were often attributed to him, such as an ultra-Malay nationalist, the truth was that most of the Chinese and Indians respected and understood the essence of the social contract that was agreed to by all the parties involved before the establishment of the national constitution. In addition, they thought highly of Mahathir's leadership. They understood the government's objectives and actions and felt that the government did not marginalise them under his leadership. All citizens were entitled to their rights and privileges justly and legally following the national constitution's provisions.

The dominant leadership qualities of Razak and Mahathir in leading the nation-state of Malaysia had been successful in moving the aspirations and agendas for the development and modernisation of the nation-state based on their achievements. This success, coupled with their achievement-oriented leadership, involvement, and commonalities in supporting their leadership, is also essential because close collaboration between the two sides is a significant factor in the 
success of the Malaysian nation-state in achieving world-class development and modernisation.

\section{Conclusion and Recommendations}

This study has explored, identified, and discussed in depth the qualities of Razak's and Mahathir's achievement-oriented leadership in the context of the development of the Malaysian nation-state. The qualities of their leadership are considerably similar, even though they have different personalities and characters. The elements of leadership that they highlighted based on this study are stimulating people's intellectual, injecting people's motivation, structured in leading, idealising influence, emphasising togetherness, emphasising the practice of good values in leading, firm in leading, confident in leading, individualising consideration, visioning the future and appreciating the people. The qualities of leadership that they highlighted based on this study were stimulating people's intellectual capacity, motivating people, careful planning, demonstrating influence, emphasising togetherness, emphasising good values, exhibiting firmness, demonstrating self-confidence, being considerate, envisioning future and acknowledging people's contribution.

Despite the same leadership qualities, the key qualities underlying the leadership of these two leaders are more or less the same. The three main qualities of Razak's leadership are stimulating people's intellectual capacity, well-planning and motivating people in leading the country. Meanwhile, Mahathir's three most important leadership qualities are stimulating people's intellectual capacity, motivating people, and cultivating good values. Thus, it is apparent that these two leaders prioritise stimulating people's intellectual capacity and motivating people in leading the country. While the qualities that differentiate these two leaders are the qualities of careful planning and cultivating good values. It implies that Razak is a leader who prioritises order in leading, while Mahathir champions his good values in addition to the other two shared qualities practised by them: stimulating people's intellectual capacity and motivating people. The two shared qualities practised by these leaders are given priority by them because of the circumstances of the people and the country. During that time, Malaysia was relatively new to independence. Therefore, there are still many efforts that needed to be accomplished by the country's leaders, especially for the people, so that they are inspired and motivated to become better human capital for the country. Strong cooperation between the people and the ruling leaders can form a strong and stable force and, hence, facilitate the process of development and modernisation of the country dreamed of by a nation-state. This also could help to place Malaysia at par with the other developed countries globally. 
The results of this study which are the qualities of leadership identified has two main social implications. The implications are first, establishing the importance of achievement-oriented leadership with a specific set of leadership qualities that can inspire and motivate the people to work hand in hand with the government to achieve the goals and agendas of national development and modernisation; and secondly, emphasising the importance of the leaders' roles in determining and shaping the nation-state's definition that should be created and adopted in a country. Despite significant research findings and valuable social implications of this study, there is a limitation. The limitation is that the research data focused solely on the texts of Razak and Mahathir's speeches during the New Year and National Day. This leads the study to focus on their qualities of leadership based merely on their speech text. Therefore, future studies should first, enrich the study of the existing speech texts by analysing other speech texts they delivered in the same year so that higher levels of data fulfilment can be achieved. Second, adding research sources such as documents on the policies launched during their administration and interviews with politicians and academicians on their leadership can reinforce the findings. The study on Razak and Mahathir's leadership in leading Malaysia is still limited despite the advantages that could be learned and benefited from their leaderships. Hence, a further study of their leaderships is relevant to be continued.

\section{Acknowledgements}

This article is based upon research supported in part by the Fundamental Research Grant Scheme (FRGS) 1/2017, under project Vote 1650, University Tun Hussein Onn Malaysia and Ministry of Higher Education, Malaysia. Any opinion, findings, conclusions, or recommendations expressed in this article are those of authors and do not necessarily reflect any supporting institutions' views.

\section{References}

Abdullah, W. J. (2019). The Mahathir effect in Malaysia's 2018 election: The role of credible personalities in regime transitions. Democratisation, 26(3), 521536.

Alqahtani, K. (2020, October 19). Concept of success through transformational leader on governmental organization performance in the Kingdom of Bahrain: A multiple case study approach. Retrieved from https://ssrn.com/abstract=3714469 
Arifin, F. M., \& Othman, N. (2018). The dynamic of policymaking process in Malaysia. International Journal of West Asian Studies, 10(1), 74-84.

Baharuddin, S. A. (1990). Masyarakat Malaysia yang membangun. Kuala Lumpur: Dewan Bahasa dan Pustaka.

Basri, A. F., Ahmad, A. H., \& Aziz, A. R. (Ed.). (1987). Isu-isu perpaduan nasional: Cabaran, pencapaian \& masa depan. Sintok: Sekolah Pengajian Asasi Universiti Utara Malaysia.

Beng, O. K. (2006). Mahathir as Muslim leader. Southeast Asian Affairs, 2006(1), 172180.

Boyatzis, R. E. (1998). Transforming qualitative information: Thematic analysis and code development. Thousand Oaks: SAGE Publications.

Bunnell, T., Barter, P. A., \& Morshidi, S. (2002). Kuala Lumpur metropolitan area: A globalising city-region. Cities, 19(5), 357-370.

Cheah, J. L. S., \& Ahmad, M. K. (2017). Confucian value-based leadership communication: A study on Tun Dr. Mahathir Mohamad. Jurnal Komunikasi: Malaysian Journal of Communication, 33(3), 140-156.

Cheah, J. L. S., Yusof, N., \& Ahmad, M. K. (2017). Tun Dr. Mahathir's Leadership Communication: The Confucian Perspective. SHS Web of Conferences, 33. https://doi.org/10.1051/shsconf/20173300060

Danto, E. A. (2008). Historical research. Oxford: Oxford University Press.

Embong, A. E. (2001). Negara bangsa: Proses dan perbahasan [Nation state: Processes and debates]. Bangi: Penerbit UKM.

Embong, A. R., Hassan, H., \& Ibrahim, N. A. (2016). The representations of leadership by example in editorial cartoons. Malaysian Journal of Communication, 32(1), 625-650.

Haggard, S. (2000). The politics of the Asian financial crisis. Journal of Democracy, 11(2), 130-144.

Hussin, R. (1999). Teori pergantungan dan cabaran wawasan Malaysia 2020. Jurnal Kinabalu, 5, 100-134.

Ibrahim, R. (2007). Multiculturalism and education in Malaysia. Culture and Religion, 8(2), 155-167.

Jackson, S., \& Mosco, V. (1999). The political economy of new: technological spaces: Malaysia's Multimedia Super Corridor. Journal of International Communication, 6(1), 22-40.

Jaes, L. (2017). Akal budi tempatan dalam pengurusan pembangunan oleh Soeharto, Mahathir dan Lee Kuan Yew (Ph.D. thesis), Universiti Utara Malaysia, Sintok, Malaysia.

Jomo, K. S., \& Sundaram, J. K. (2004). The new economic policy and interethnic relations in Malaysia. Geneva: UNRISD. 
Jonas, A. E., \& Wilson, D. (2018). The nation-state and the city: Introduction to a debate. Urban Geography, 39(9), 1418-1420.

Khattab, U. (2004). Wawasan 2020: Engineering a modern Malay(sia) state campaigns and minority stakes. Media Asia, 31(3), 170-177.

Lovelace, J. B., Neely, B. H., Allen, J. B., \& Hunter, S. T. (2019). Charismatic, ideological, \& pragmatic (CIP) model of leadership: A critical review and agenda for future research. The Leadership Quarterly, 30(1), 96-110.

Liu, H., Dust, S. B., Xu, M., \& Ji, Y. (2021). Leader-follower risk orientation incongruence, intellectual stimulation, and creativity: A configurational approach. Personnel Psychology, 74(1), 143-173.

McCleskey, J. A. (2014). Situational, transformational, and transactional leadership and leadership development. Journal of Business Studies Quarterly, 5(4), 117.

Mcdowell, B. (2013). Historical research: A guide for writers of dissertations, theses, articles and books. Abingdon: Routledge.

Othman, M. R. (2006). Sejarah pembinaan negara bangsa. Kuala Lumpur: Penerbit Universiti Malaya.

Mohamad, M. (1996). Islam-the misunderstood religion. JATI-Journal of Southeast Asian Studies, 2, 1-10.

Mohamad, M. (2012). Doktor umum: Memoir Tun Dr. Mahathir Mohamad. Petaling Jaya: MPH Group Publishing.

Morgan, G., \& Smircich, L. (1980). The case for qualitative research. Academy of management review, 5(4), 491-500.

Nathan, K. S. (1995). Vision 2020 and Malaysian foreign policy: Strategic evolution and the Mahathir impact. Southeast Asian Affairs, 22, 220-237.

National Archives of Malaysia. (2019, November 25). Tun Razak, catalyst of people/national development. Retrieved from http://www.arkib.gov.my/en/web/guest/tun-razak-penggerakpembangunan-rakyat-negara

Nik Mahmud, N. A., Salleh, M., Harun, A. G. (2011). Biografi Tun Abdul Razak: Negarawan dan patriot. Bangi: Penerbit Universiti Kebangsaan Malaysia

Osborne, T. (2018). Treaty of Westphalia/Peace of Münster (1648). The Encyclopedia of Diplomacy, 1-9.

Raj, P., Wahab, S. A., Osman, S. I. W., Zawawi, N. M., \& Fazal, S. A. (2018). Sustainable Development and Innovation: Reviewing the Concept and Malaysian Participation. International Journal of Academic Research in Business and Social Sciences, 8(9), 1212-1226.

Rohman, M. A., \& Sabri, A. Z. S. A. (2017). Kempen "Kepimpinan melalui Teladan" semasa era pemerintahan Tun Dr. Mahathir Mohamad di Malaysia. Sains Humanika, 9(2), 15-23. 
Rudner, M. (1977). Education, development and change in Malaysia. Japanese Journal of Southeast Asian Studies, 15(1), 23-62.

Sendjaya, S., Pekerti, A., Härtel, C., Hirst, G., \& Butarbutar, I. (2016). Are authentic leaders always moral? The role of Machiavellianism in the relationship between authentic leadership and morality. Journal of Business Ethics, 133(1), 125-139.

Suhaimy, K. A. M. (2009). Pemikiran pembangunan berteraskan system nilai budaya: Kajian terhadap pendekatan Dr. Mahathir Mohamad 1981-1986 (Ph.D. thesis), Universiti Utara Malaysia, Sintok, Malaysia.

Sundaram, J. K., \& Cheek, A. S. (1988). The politics of Malaysia's Islamic resurgence. Third World Quarterly, 10(2), 843-868.

Suppiah, S. M., Ahmad, M. K., \& Gunasekaran, H. N. (2018). Mahathir's leadership communication: Exploring the Indians' community experience. Jurnal Komunikasi: Malaysian Journal of Communication, 34(2), 205-222.

Taylor, R. D. (2003). The Malaysia experience: The multimedia super corridor. In M. Jussawalla \& R.D Taylor (Eds.), Information technology parks of the Asia Pacific: Lessons for the regional digital divide (pp. 64-118). New York: M.E Sharpe.

van Houwelingen, G., van Dijke, M., \& De Cremer, D. (2015). Getting it done and getting it right: Leader disciplinary reactions to followers' moral transgressions are determined by construal level mindset. The Leadership Quarterly, 26(5), 878-891.

Welsh, B. (2005). Malaysia in 2004: Out of Mahathir's Shadow? Asian Survey, 45(1), 153-160.

Cite this article (APA):

Mohamad Suhaimy, K.A., Razali, N.A., Lutfan, L., Sabtu, M.A., Othman, M.F., Lee Abdullah, M.A.I., \& Hanapi, M.S. (2021). Leader's Achievement-Oriented Leadership Model Framework in the Development of Malaysian Nation-State. JATI-Journal of Southeast Asian Studies, Volume 26(1), June 2021, 1-20

Date received: 18 February 2021 Date of accepted: 21 June 2021 